\title{
Literary Quotations in Bilingual Dictionaries: A Case Study of a Nineteenth-century Dutch-Chinese Dictionary
}

\author{
Audrey Heijns, School of Foreign Languages, Shenzhen University, \\ Guangdong, China (ajheijns@gmail.com)
}

\begin{abstract}
The phenomenon of literary quotations in dictionaries finds its origin in the days when the search for equivalents was intertextual rather than interlingual based. For both monolingual and bilingual dictionaries the purpose of literary quotations is to supply evidence of usage and illuminate the meaning of the relevant headword, with the difference that for bilingual dictionaries this is done via translation. This article examines this phenomenon in a nineteenth century Dutch-Chinese dictionary by analysing sample sentences that the compiler has extracted from original Chinese texts. Discussion of examples from different types of text will probe the functioning of the quotations and the intention of the compiler. The inclusion of the quotations in the dictionary appear to be the result of both linguistic and cultural intention, in the sense that they are revealing of the syntax of Chinese but also aspects of Chinese culture. These findings will contribute to the understanding of the practice of the inclusion of literary quotations in bilingual dictionaries and the role of the compiler in introducing foreign cultural aspects.
\end{abstract}

Keywords: LITERARY QUOTATIONS, BILINGUAL DICTIONARIES, DUTCH, CHINESE, NINETEENTH CENTURY, LEXICOGRAPHICAL PRACTICE, ROLE OF THE COMPILER

Opsomming: Literêre aanhalings in tweetalige woordeboeke: 'n Gevallestudie van ' $n$ negentiende-eeuse Nederlands-Chinese woordeboek. Die voorkoms van literêre aanhalings in woordeboeke dateer uit die dae toe die soeke na ekwivalente eerder op interteks as op intertaal gebaseer is. Vir beide eentalige en tweetalige woordeboeke was die doel van literêre aanhalings om bewys van gebruik te lewer en om die betekenis van die toepaslike trefwoord uit te lig, met dié verskil dat dit by tweetalige woordeboeke via vertaling geskied het. In hierdie artikel word dié verskynsel in 'n negentiende-eeuse Nederlands-Chinese woordeboek ondersoek deur die analisering van voorbeeldsinne wat die samesteller uit oorspronklike Chinese tekste onttrek het. In die bespreking van voorbeelde uit verskillende tekstipes sal die funksie van die aanhalings en die bedoeling van die samesteller deeglik ondersoek word. Dit wil voorkom of die insluiting van die aanhalings in die woordeboek die resultaat van beide taalkundige en kulturele doelwitte is aangesien sowel die sintaksis van Chinees as aspekte van die Chinese kultuur weerspieël word. Hierdie bevindings sal bydra tot 'n beter begrip van die praktyk van insluiting van literêre aanhalings in tweetalige woordeboeke en van die samesteller se rol in die bekendstelling van vreemde kulturele aspekte. 
Sleutelwoorde: LITERÊRE AANHALINGS, TWEETALIGE WOORDEBOEKE, NEDERLANDS, CHINEES, NEGENTIENDE EEU, LEKSIKOGRAFIESE PRAKTYK, ROL VAN DIE SAMESTELLER

\section{Introduction}

The practice of including literary quotations in dictionaries dates from the days when the compilation of dictionaries was based on the search for intertextual rather than interlingual equivalence. "In the European tradition, it was the text that gave the initial impetus to the search for equivalence." (AdamskaSałaciak 2010: 388) For the well-known English lexicographer Samuel Johnson the primary role of quotations in the Oxford English Dictionary (OED) was to supply evidence of usage and illuminate the meaning of a word (Brewer 2010: 101). As Brewer further notes, the quotations in the $O E D$ were

supposed to be constitutive rather than illustrative of meaning: that is, the lexicographers deduce the meaning of words from their quotations (rather than deduce the meanings of their quotations from their pre-determined definitions). Clearly these quotations and definitions are functioning quite differently, and their inclusion in the $O E D$ looks to be the result of cultural not just linguistic intention on the part of the lexicographers, deriving from assumptions of the kind articulated by Burchfield, that not to consider such examples of usage 'leave one looking at a language with one's eyes partly blind-folded.' (Brewer 2010: 112-113)

Hence beyond the linguistic intention of inclusion of literary quotations in the dictionary, there is an additional purpose: the cultural intention, i.e. the quotations are included for "the purpose of educating via exposure to morally instructive sentiments" (Brewer 2010: 100). As a result of the inclusion of literary sources, the $O E D$ ultimately functioned not only as a word-list but also as "an intellectual history of an entire culture" (Brewer 2010: 100-101).

The aim of this study is to examine the intention of the compiler and the functioning of the literary quotations in the nineteenth-century Dutch-Chinese dictionary Nederlandsch-Chineesch Woordenboek met de Transcriptie der Chineesche Karakters in het Tsiang-Tsiu Dialekt 荷華文語類參 Hô Hoâ Bûn-Gí Luī-Ts'am [Dutch-Chinese Dictionary with Transcription of Chinese Characters in Zhangzhou Dialect]. The compiler of this dictionary was the Dutch sinologist Gustaaf [also spelled Gustav] Schlegel (1840-1903) who started collecting the data for the dictionary upon his arrival in China at the end of the 1860s. During his years in China, in the Dutch East Indies (present day Indonesia) and upon his return in the Netherlands, Schlegel continuously worked on the dictionary and arranged funding for publication. The publication process of the dictionary has been described in detail by Koos (P.N.) Kuiper in his study on early Dutch sinologists, which also contains an elaborate overview of the contents of the dictionary and its reception (Kuiper 2017). Previously, I have examined aspects of equivalence in the dictionary (Heijns 2020). The current article, however, 
aims to analyse Schlegel's practice of including phrases that he extracted from Chinese source texts.

Schlegel considered the Chineesch-Hollandsch woordenboek van het Emoi dialekt [Chinese-Dutch dictionary of the Amoy Dialect] compiled by Johannes J.C. Francken (1838-1864) and Carolus F.M. de Grijs (1832-1902) as the counterpart of his dictionary, as he noted in the introduction to his dictionary (Schlegel 1886: 2). Indeed, Schlegel only produced a Dutch-Chinese dictionary and the inclusion of many Chinese concepts implies that Schlegel's work method resembled compilation of a unidirectional dictionary. Since the source language of Schlegel's dictionary is the language of the user, it can be considered an active or encoding dictionary, because "its purpose is to support the encoding of expressions in a foreign language" (Osswald 2015: 1981). Schlegel introduced typical Chinese cultural aspects under associated Dutch headwords. It is clear from the quotations that he had already done the translation from Chinese into Dutch beforehand and he inserted the phrases into the relevant entries in the dictionary according to terms in his Dutch version, sometimes even using the same phrase under more than one headword, where suitable.

What follows here, is an analysis of the literary quotations included in the dictionary which will shed light on the intention of Schlegel, similar to the examination of Brewer into Johnson's. The difference is of course the fact that Schlegel's is a bilingual dictionary bringing the complicating factor of anisomorphism because it is not only about the meaning and use of words but also about finding equivalents between words in two different languages. To quote Adamska-Sałaciak again: "[...], bilingual lexicography straddles the domains of linguistics and translatology" (2010: 389). Hence, in addition to discussing various examples of literary quotations and their purposes with either a linguistic or a cultural intention, I will also comment on the translation. Ultimately, I will conclude with what the inclusion of literary quotations means in terms of the functioning of the dictionary, not only as a word-list but also as an intellectual history of China's culture and Schlegel's contribution to it in terms of selection and translation.

\section{Background to the Compiler and his Dictionary}

Tasked with the responsibility of teaching Chinese to Dutch candidates who passed the entrance exam to study Chinese at Leiden University, Schlegel was confronted with the lack of good teaching material. Back then the students who were admitted to the course were trained to become Chinese interpreters in the Dutch East Indies. ${ }^{1}$ As Kuiper notes:

In the 1870s, Schlegel had complained several times that there were no good language tools for the students. But in 1888, three of the four volumes of Schlegel's Dutch-Chinese dictionary had appeared, and the fourth volume would be completed in 1890. This must have been a great help to the students in making translations from Dutch into Chinese. Moreover, Francken and De Grijs's Amoy-Dutch diction- 
ary had appeared in 1882, and although it was not as good as Carstairs Douglas's dictionary, it was certainly useful. Of course, the students would also make use of Williams' and Douglas' dictionaries. (Kuiper 2017: 431, my italics)

In addition to the goal of helping translators at work in the Dutch East Indies, Kuiper emphasizes the need of dictionaries for students learning Chinese. Schlegel's teaching method was to have the students manually copy (part of) textbooks. Schlegel taught the students the spoken language of the Tsiang-tsiu [Zhangzhou] dialect, Chinese moral maxims and oral translations from Dutch into Chinese and vice versa. In Schlegel's view, reading and translating "until you think in the same vein as the Chinese" (Schlegel 1892: 48) was part of the process of learning Chinese. Study of the Chinese language prepared the students for their future career as Chinese interpreter that involved oral interpreting in court, and written translations from Dutch into Chinese and viceversa. Having done both (study Chinese and serving in the Dutch East Indies) Schlegel was keenly aware of the urgent need of a good dictionary, even though in practice, the interpreters in the Dutch East Indies often worked with the help of Chinese clerks, by explaining orally (in Chinese) the contents of the Dutch text to be translated which the Chinese clerk would then put into written Chinese.

Schlegel's dictionary is arranged alphabetically by Dutch entries and provides Chinese equivalents in Chinese characters with Hokkien transcription. Hokkien, or minnan dialect, was the most commonly spoken language among ethnic Chinese in the Dutch East Indies and was therefore essential for the interpreters to learn. As Schlegel explains in the introduction, his aim was to help Dutch interpreters of Chinese in the Dutch East Indies with their work. In his idea of learning Chinese, Schlegel stressed the importance of reading and translating source texts, therefore in the dictionary, he always strove to provide (sample) sentences from original Chinese texts. Despite sporadic mention of the source of the original text, my findings show that Schlegel draws on a great number of Chinese texts, including classical texts (including the Lunyu 椧語 [Analects], Mengzi 孟子 [Mencius] and Zhuangzi 莊子 [Zhuangzi]), historical works (Shiji 史記 Records of the Grand Historian, Hanshu 漢書 History of the Han, Jinshu 晉書 History of the Jin), poetry (Shijing 詩經 Book of Songs) and novellas (Jingu qiguan 今古奇觀 Wonders Old and New) as well as a mixture of other works (Kangxi zidian 康熙字典 Kangxi Dictionary, Taiping guangji 太平廣記 [Extensive Records of the Taiping Era], Huajianji 花箋記 Flowery Letterhead, Wufengyin 五鳳吟 Wufengyin). The many examples, comments and references to other experts resulted in this dictionary becoming a bulky work. It was printed in four volumes over a period of six years (1884-1890) with a total of more than 5,000 pages.

According to Schlegel, he included phrases mainly to illustrate the use of translated words: "The Chinese being emphatically a language of phrases, it was of importance to show, by extracts from native sources, the collocation in which words occur." (Schlegel 1886: 17-18) Moreover, Schlegel concurred with 
Carstairs Douglas (1830-1877) and cites from the preface of his Chinese-English Dictionary of the Vernacular or Spoken Language of Amoy: "The whole style and character of Chinese thought and expression is so different from the nearest English (read European) equivalents, that the work of reversing a dictionary, which at first sight seems very easy, would really be enormous, falling not very far short of the original composition" (Schlegel 1886: 18; Carstairs Douglas 1873: ix).

\section{Analysis of Literary Quotations}

Considering that Franken and De Grijs had opted for the vernacular in their dictionary, Schlegel himself claims that he "decided upon the written language (the so-called Book-language) for the compilation of my Dictionary" (Schlegel 1886: 2). $\mathrm{He}$ also stresses that "[c]omplete sentences and expressions from Chinese authors were copied out, and inserted alphabetically into the Dictionary, at the different words contained in such a sentence or expression." (Ibid.) In other words, the user can rest assured that the sample sentences were from genuinely Chinese source texts.

It is clear from what seems a random selection of quotations that Schlegel made no difference between the types of literary genres. In the pre-modern Chinese literary tradition, i.e. up until the late nineteenth-early twentieth century, literature was "intended to be useful, exert an influence on readers that was simultaneously intellectual, moral and aesthetic" (Idema and Haft 1997: 9). The genres included two literary forms, poetry and the essay, but more broadly it also included historical and philosophical works (McDougall 1971: 2). This is different from the Western literary tradition, which also included fiction and drama. Hence, given their background, some Western translators of Chinese literature with their Western ideas found that Chinese fiction provided an excellent source of information about the Chinese people and their culture, and they regarded fiction as a reflection of Chinese society (Wyllie 1964: 201-202). In China, however, it was not until the early twentieth century that norms started to change, and drama and fiction became recognized literary genres.

As stated above, Schlegel's primary aim with the dictionary was to help Dutch interpreters of Chinese in the Dutch East Indies with their work, and it was also meant to be a tool for students to learn Chinese. In terms of lexicographic functions as proposed by Henning Bergenholtz and Sven Tarp, the function of Schlegel's dictionary and the inclusion of literary quotations are primarily "communication-orientated" to solve problems "during production, reception or translation phases" of the communication process (Bergenholtz and Tarp 2003: 174). This is clear from the examples in Schlegel's dictionary as shown under "linguistic intention" below, where semantic and grammatical aspects are analysed in the quotations. Yet, another function of Schlegel's dictionary and the inclusion of literary quotations is to a certain extent also "knowledge-orientated" in that it provides "additional information on some topic, e.g. general cultural and encyclopaedic information, specialised informa- 
tion regarding a scientific discipline (biology, geology etc) or information about a specific language related to the language-learning process (for example the learning of a foreign language)" (Bergenholtz and Tarp op cit.). This is clear from the examples from Schlegel's dictionary under "cultural intention" below, where additional information is given about Chinese culture and history. In the final category "failed intention" there are examples of literary quotations that are not very helpful and provide neither linguistic nor cultural help.

\subsection{Linguistic Intention}

A very practical example of a literary quotation from Huajianji can be found under the headword "aanbieden" [to offer] (Schlegel 1886: 34-35):

hij begon haastig bij het lamplicht eene memorie aan Z.M. [Zijne Majesteit] te schrijven, waarin hij zich aanbood om naar de grenzen te trekken en de rebellen te bestrijden.

[he hastily started writing a memorial to HM [His Majesty] by the lamplight, in which he offered to go to the border to fight the bandits.]

燈下連忙寫表文, 願出邊關征賊寇。

The translation is accurate and the use of yuan 願 for "aanbieden" in the sense of "to be willing to" makes sense. In fact, this whole phrase appears useful. The description of the action (writing), the name of the document (memorial) and the topic of voluntary assistance (fighting) provide practical information and would have been useful for the translations that the translators had to do at work.

A good example of what Schlegel regards as a Chinese phrase can be found in the entry "uitlokken" [to tempt, entice] (Schlegel 1884: 312):

Kiun-tsan wist door het middeltje om den tijger uit het bosch te lokken, Ki-sing in zijn eigen huis te verschuilen.

[By means of luring the tiger out of the forest, Junzan managed to hide Qisheng in his own home.]

君讚用調虎離山之計, 將琪生藏在自己家裡

By citing this phrase from Wufengyin, Schlegel shows that in Chinese "uitlokken" uses a construction with yong 用 [use], diao 調 [move] and $j i$ 計 [a plan]. This is typically an example to show there is no direct equivalent, but rather a phrase that the user has to follow. The difficulty, however, might be for the user to find out the term for "uitlokken" in the Source Text (ST) because Schlegel does not give an explanation.

Another example from Wufengyin can be found under "Uitredden" [to rescue from] (Schlegel 1890: 322): 
het was Roodbaard, die aan het hoofd van meer dan honderd bandieten Ki-sing uit de gevangenis kwam redden.

[It was Redbeard, who as the leader of more than one hundred bandits came to rescue Ki-sing from prison.]

却是紅鬚領著百餘嘍囉進來却獄救琪生。

Note how Schlegel changed the gerundive form lingzhe [leading] into the wordier clause "who as the leader of" which seems unnecessary. Both these literary quotations from Wufengyin are sample sentences with enough context for the user to understand the meaning and use.

An example of a more grammatical purpose is the suggestion by Schlegel on how to formulate questions in Chinese. Schlegel quotes from the Confucian classic the Mencius to give an example of an interrogative sentence in Chinese. The exact same phrase appears under the two entries "vraagwoord" (question word) (Schlegel 1890: 971) and "vragen" (to ask) (Schlegel 1890: 976):

De Koning vroeg: was het park van koning Wen niet zeventig vierkante mijlen groot? [The King asked: wasn't the size of King Wen's park seventy square miles?] 王問曰。文王之直方七十里, 有諸。

The construction in Chinese: "clause, is this true?" shows the user that the last two characters you zhu are the question words for "is it true?". These are particles used in classical Chinese. Compare with D.C. Lau's version, which translated more literally: "Is it true that the park of King Wen was $70 \mathrm{li}$ square?" (Mencius 2003: 29). This literary quotation is a good example of how to write interrogatory sentences in classical Chinese and the inclusion mainly functions as a grammatical instruction.

It is striking that some of the most useful and practical sentences come from the so-called caizi-jiaren 才子佳人 (talent and beauty) stories which are described by Cynthia J. Brokaw as:

the "talent and beauty" (caizi jiaren 才子佳人) love stories, appearing first in the late Ming dynasty and continuing to be written in some numbers well into the nineteenth century. These usually rather short works concerned talented scholars and beautiful (and often even more talented) women who, after lengthy and sometimes ludicrous impediments, marry and live happily ever after. They vary widely in quality: "At their best these novels [...] are reminiscent of eighteenth-century French comedies. At their worst, however, they are pedantic and soporific Chinese equivalents of the dime novel."2 With convoluted plot lines, most were written in a "beautiful and refined" style appropriate to their subject matter; they seem to have been intended for a fairly literate readership. (Brokaw 2007: 488-489)

Schlegel read many of these caizi-jiaren stories, as evidenced by the many quotations from works such as Wufengyin, Huajianji and Yulouchun 玉樓春 [Jade Tower Spring]. These works are written in the vernacular style, and a work 
such as Huajianji even has some local dialect (Cantonese) included. Hence the language of these works is rather colloquial and relatively easy to read and use.

\subsection{Cultural Intention}

Far more difficult are the literary quotations that introduce Chinese culture. These come in the form of philosophical claims such as the following from the Mencius under the headword "buigen" (to bow, bend), where it is used more figuratively in the sense of "to submit, yield" (Schlegel 1886: 720).

die door rijkdom en aanzien niet brooddronken wordt, niet afwijkt, ook als hij arm en geminacht is, en niet voor geweld en gezag buigt, dien kan men een' groot man noemen.

[He] who does not become wasteful by wealth and prestige, does not stray even though he is poor and despised, and does not bow to violence and authority, he may be called a great man.

當貴不能淫。貧賤不能移, 威武不能屈。此之謂大丈夫 (Mencius Tengwengong xia 7)

Written in classical Chinese, the ST is dense and compact. In order to make it work in a foreign language, it is necessary to add words when translating from classical Chinese into a European language to make it grammatically sound, because of the huge differences between the languages. This is a feature of all Chinese classical texts and not limited to Confucian texts or poems from the Shijing as shown below. In the example from the Mencius, there is also a certain pattern in the Chinese, if looked at word for word, which cannot be translated literally. In Schlegel's translation the notion of "buigen" comes out clearly, and for the three criteria of "a great man", which follows the Chinese repetition of $b u$ [not] clarifies what a great man does not do. This is for instance different in comparison with James Legge's translation: "to be above the power of riches and honours to make dissipated, of poverty and mean condition to make swerve from principle, and of power and force to make bend - these characteristics constitute the great man" (Legge 1875: 218). Legge has omitted negation, but opted for repetition of "to make + verb".

Another example is the inclusion of poetry under the headword "Rijm" [Rhyme] (Schlegel 1884: 633-634). Schlegel includes poems from the Book of Songs 詩經 which is a collection of over 300 poems dating from the eleventh to seventh centuries BC. Although the purpose of quoting the poems here is primarily to show the differences in rhyme patterns, it is also a good introduction to classical Chinese poetry. The Book of Songs is regarded as learning material and a source of four character-idioms known in Chinese as chengyu. In imperial China, every educated person would have read it and would have been familiar with the poems. For three types of rhyme patterns, there are two stanzas from the poem Guan ju 關睢 [Mandarin ducks], and one from the poem Tuju 兔置 [Rabbit net], 
while for the other six types there are only explanations, no examples. A closer look at the translations of the stanzas shows that Schlegel follows Legge's version quite closely although Schlegel is less wordy as the following stanza from Guan ju (Schlegel 1884: 634) shows:

Hij zocht haar, en vond haar niet

En wakend en slapend dacht hij aan haar

Hij dacht lang; hij dacht lang

En wentelde zich om en om

[He sought her and found her not

And waking and sleeping he thought of her

He thought long; he thought long

And turned around and around]

\section{求之不得 \\ 寤㝥思服 \\ 悠哉悠哉 \\ 輾轉反側}

From the ST we can see that it is four characters per line, a pattern which is lost in translation. The ST is extremely terse, for example the four characters of the first line word-for-word is literally: seek-it-not-obtain. When compared with Legge's version, the first two lines are translated in a similar way: "He sought her and found her not, / And waking and sleeping he thought about her" (Legge 1871, as quoted in Minford and Lau 2002: 75). But then the third and fourth lines, where Legge has: "Long he thought; oh! long and anxiously / On his side, on his back, he turned and back again" (Ibid.). ${ }^{3}$ This shows that Legge's version is wordier than Schlegel's, who sticks more closely to the ST, retaining the repetition in line 3 just like in the Chinese, and in line four he retains the meaning of the ST where Legge is overtranslating: adding "anxiously" in the third line and an extra turn in the fourth line. Overall, the inclusion of literary quotations from the Book of Songs is informative about Chinese poetry, even though not directly practical or useful for the user's translation tasks. However, there was a poetry requirement for the major period of the official imperial examinations keju in China, in connection with the notion that "the study and practice of poetry encouraged careful writing" (Su Shi's opinion according to Murck 2000: 52). It is likely that, in Schlegel's view, inclusion of poems and reading poetry would help the student or translator of Chinese, not necessarily in the practice of the language but rather the understanding of it as "culture". So in all probability, besides showing the rhyme patterns, for Schlegel it must have been a method of exposing the user to Chinese poetry, purely for poetry's place in the Chinese literary tradition.

An even more culturally loaded entry is the headword "Fata-Morgana", with "Luchtspiegeling" in brackets, in the sense of "mirage" or "optical illusion." Here Schlegel quotes from and refers to a total of six different Chinese and 
Western texts as evidence for the meaning and use of the word, hence the entry reads almost like a research note. (Schlegel 1886: 1168-1170) After giving some basic equivalents, including huanjing 幻境, shen 傆, shenlou 愿樓 etc., Schlegel cites the description from the entry shen 蜃 [clam] in the Chinese reference work the Kangxi Dictionary. The description explains the origin of the clam in connection with the phenomenon of "mirage", that is that shen is "a kind of dragon whose exhaled breath forms the shape of towers and cities. If it starts raining one can see them and one calls them Shen towers or Seamarket." This is a kind of optical illusion. Here, Schlegel refers to the French engineer and sinologist Édouard Biot's (1803-1850) 'Note sûr un phénomène de mirage Indiqué par quelques textes chinois' [A note on the phenomenon of "mirage" as indicated by some Chinese texts] published in Journal Asiatique 1848/07: 518-520. Here, Schlegel adds in brackets that "the text has been translated inaccurately [by Biot]" as a warning to the user (Schlegel 1886: 1168-1169).

Among the most important quotations in this entry that enlighten the user are from the Taoist work Zhuangzi and historical works History of the Jin 晉書 and History of the Song 宋書, that both convey the phenomenon of mirage in cultural sense, but will be difficult for the user to apply in translation. Schlegel notes that according to Zhuangzi "wild horses and dust" 野馬也塵埃也 were mirages. Schlegel goes on to explain this concept with quotes by commentators on the Zhuangzi, among which is the following quotation (Schlegel 1886: 1169):

De commentator op de "Wilde paarden" van Zhuangzi zegt: wanneer de zon op het stof schijnt, en een lichte wind die in de wildernis doet stuiven, noemt men dit, met een woordverdraaiing, Zonnegloed; de eenvoudige man, die dit verschijnsel ontwaart, noemt het "Wilde paarden"; de dorstige, die het ontwaart, houdt het voor stromend water.

[The commentator on "Wild horses" of Zhuangzi says: when the sun shines on dust and a light wind blows it into the wilderness, this is called "solar glow" in a word distortion; the simple man who observes this phenomenon calls it "wild horses"; a thirsty person who perceives it sees it as running water.]

莊子野馬注云。日光著塵, 微風吹之曠野中。轉名之為陽筷。愚夫見之, 謂之野 馬。渴人見之, 以為流水。

In terms of language, these sentences in Chinese are again terse and pithy. In this quotation, there is enough context to understand the notion of "wilde paarden" [wild horses]. The motivation to include this phrase must have been the explanation of the idea of "wild horses" and how it is interpreted. Problematic in the translation is the meaning of zhuan ming which Schlegel translates as "woordverdraaiing" [word distortion]. Incorrect punctuation has separated zhong from zhuan, meaning to shift or transfer. The action of the wind causes the dust to move and that changed its name into "solar glow." On the whole, the quotation is illuminating of the concept of "wild horses" but it is not very convincing in terms of being equivalent to "fata-morgana". 
In terms of meaning, the literary quotations from other historical sources come closer to the idea of a "mirage" in the sense of "optical illusion". Two examples will illustrate this. The first "Water reflection" 水影 is from the History of the Jin (Schlegel 1886: 1169) and the second "Earth mirror" 地鏡 is from the History of the Song (Schlegel 1886: 1169-1170):

Ten tijde van Fu Jian (AD 357-385) zag men in Chang'an eene Waterspiegeling, die van verre er uitzag als water; zag men op de aarde, dan ontwaarde men echter menschen. Zij duurde tot het jaar van Jian (385) en verdween toen.

[During the Fu Jian (AD 357-385) era the people in Chang'an saw a Water reflection which looked like water from afar; but on the earth they saw people. This continued until the year of Jian (385) and then disappeared.]

符堅時長安有水影。遠觀若水。視地則見人。至堅晚年而止

in het 25e jaar der periode Yuanjia der regeering van Keizer Wen der Song-dynastie (AD 448), zag men des winters verre ten zuiden der stad Qingzhou iets als de schaduw van water in het land, hetgeen men "Aardspiegeling" noemde.

[In the twenty-fifth year of the Yuanjia administration ruled by Emperor Wen of the (Liu) Song Dynasty (AD 448), people saw in winter far south of the city of Qingzhou a kind of shadow of water in the ground, which they called "Earth mirror".]

宋文帝元嘉二十五年, 冬, 青州城南遠觀見地中如水有影, 謂之地鏡

The factual description in Chinese is rewritten by Schlegel in a more descriptive way in Dutch which is suitable for history writing. Problems in the translation are: in the first citation, wannian is not necessarily just only that one final year of 385, it is more in general "the final years" of Jian's reign period. In the second citation, his translation of "ying" as "shadow" is problematic, it should be reflection, which then corresponds with what you see in the mirror. The additional information about which the Chinese lunar year corresponds with the Western (Gregorian) calendar is very helpful. Both quotations describe the phenomenon more closely to what is understood as "mirage". It appears that Schlegel's attempt to include the Taoist concept of wild horses under "mirage" is somewhat contrived, but it was supposedly the closest concept that he could find. For the meaning of "mirage", the historical sources are more suitable. Nevertheless, it is clear from the quotes and examples under headword "fata morgana" (mirage) that Schlegel studied the "mirage" issue thoroughly, giving thought to its meaning and trying to find an equivalent. The context of the use of "wild horses and dust", "water reflection" and "earth mirror" is clear and helpful. Moreover, the many examples from historical sources show that in different periods and different places mirages were observed in China.

\subsection{Failed Intention}

There are literary quotations that are difficult to categorize. They seem to have 
neither linguistic nor cultural purpose. Take for example this quotation from "The Oil Vendor and the Queen of Flowers" 賣油郎獨佔花魁女 (hereinafter "The Oil Vendor") under "Bespatten" [splash, spatter] in the dictionary (Schlegel 1886: 452):

ik reken mij gelukkig, dat zij (mijne kleeren) door eenige droppels vocht van Mejuffrouw bespat zijn

[I considered myself lucky that they (my clothes) were splashed by a few drops of moisture from the young lady.]

有幸得沾小娘予之餘瀝

At the beginning of the entry, Schlegel provides the more commonly used character jian 漸 for this term. Although the combination of "zhan 沾... li 瀝" has the same meaning here, the entire sample sentence is quite unclear. There are too many questions: why is he feeling lucky? What type of liquid is the young lady splashing? What kind of situation would this happen? The only clue Schlegel gives is "my clothes" in brackets. It appears that there is no practical purpose for the user, neither in lexical nor in grammatical sense and the line is quoted out of context. "The Oil Vendor" is a story that Schlegel had previously published in French as "Le Vendeur-d'huile qui seul possède la reine-debeauté." As Kuiper notes: "This [publication] became one of his textbooks when teaching in Leiden, and it was read by all his students." (Kuiper 2017: 131) It is a story from Stories Old and New 今古奇觀 a collection of forty novellas originally published anonymously, but whose author was later identified as Feng Menglong 馮夢龍 (1574-1646).

Another dubious quotation is from the text Yulouchun by Baiyun Daoren [White Cloud Daoist], and concerns the explanation of an allusion in the entry bruidsnacht [wedding night] (Schlegel 1886: 715):

Van dit enkele bezoek naar den Yang toren in den bruidsnacht, ben ik dadelijk met een droom van een beer begunstigd, en ben nu reeds een half jaar zwanger.

[After this single visit to the Yang tower on my wedding night, I was immediately favoured with the dream of a bear and now I have been pregnant for six months.]

妾身花燭之夜一赴陽臺, 遂符熊夢。今已懷娠半載

If read literally, the first part of this quotation is rather cryptic: "my body in the night of candles with dragon and phoenix patterns went to the Yang tower, then had the dream of a bear". "The night of candles" stands for "wedding night," and "dream of a bear" implies that one will give birth to a son. By giving this example, Schlegel shows the use of symbols and metaphors in Chinese texts. This may be interesting information for those reading Chinese literature, but not necessarily practical for the user.

The examples of literary quotations discussed here show the great variety of texts that Schlegel had at his disposal. Even without indication of the source or explanation of the nature of the texts, many of these sample sentences are 
useful for the user. Some are practical in the sense that the meaning and use are clear and ready for use, some are interesting in that they provide information about Chinese culture. However, there are also quotations that provide neither information nor practical use and are quoted out of context. Overall, the user is exposed to a wide variety of genres of texts and different types and register of Chinese language. This kind of material is especially useful for teaching Chinese language and literature.

\section{Influential Thinking}

It is clear from the data incorporated in Schlegel's dictionary that not all correspond with its lexicographic functions as identified above. As Bergenholtz and Tarp write: "no data whatsoever should be included in a dictionary if it cannot be argued on the basis of its respective functions" (Bergenholtz and Tarp 2003: 177). Schlegel's failure to do so must have in part been the result of the limited availability of resources and perhaps also a lack of awareness. However, the selection of quotations and the method of translation must have also been influenced by his personal ideas and interests, in spite of the fact that the general expectation is that the data in the dictionary are objective. As Atkins and Rundell note:

Lexicographers, like historians, are expected to be "neutral" recorders of factsbut this is not as straightforward as it sounds (in either discipline). Departures from lexicographic neutrality are characterized as "editorializing", which is seen as a reprehensible tendency. (Atkins and Rundell 2008: 427)

This so-called "editorializing" or translational intervention is manifest in Schlegel's comments, explanations, and quotations in the dictionary. It appears that Schlegel was not alone in working this way, however. Atkins and Rundell cite the example of the aforementioned lexicographer Samuel Johnson, who, according to them, used the dictionary "to pursue personal vendettas" (Atkins and Rundell 2008: 428). In Schlegel's case, I would argue that he used the dictionary "to pursue personal interest," resulting in entries that clearly depart from lexicographic neutrality.

There is a direct link between the dictionary and the compiler's research field and literary preferences. Topics that Schlegel researched and wrote about include Chinese triads (Thian Ti Hwui: The Hung-League Heaven-Earth), prostitutes (About Prostitution in China in 1866), and Chinese astronomy (Sing Chin Khao Youen 星辰考原 Uranographie Chinoise ou preuves directes que l'astonomie est primitive et originaire de la Chine in 1875). Literary works that he had translated and published include: the Huajianji translated into Dutch as De geschiedenis van het gebloemd briefpaper [History of the Flowered Letterhead] in 1866 and aforementioned French translation Le Vendeur-d'huile qui seul possède la reine-de-beauté ou splendeurs et misères des courtisanes chinoises. [The Oil Vendor and the Courtesan, or the Splendors and Miseries of Chinese Courtesans] in 1877.

Furthermore, the method of translation is influenced by Schlegel's idea 
that Chinese is a language of phrases as explained above, he also thought that the Chinese way of thinking differed from the Dutch. He explains this in the entry "troost" [consolation] as a noun (1890: 215):

zie verder "troosten", daar een abstractum "Troost", als persoonlijkheid, niet in de Chinese taal kan gedacht worden, maar steeds door het verbum uitgedrukt wordt; b.v.: "dit is mijn eenige troost" wordt vertaald met "dit is het eenige, wat mij troost."

[See "troosten", since an abstractum "Consolation" as a personality cannot be perceived in the Chinese language, but is always expressed through a verb, for example: "this is my only consolation" is translated into "this is the only thing that comforts me."]

According to Schlegel, "troost" cannot be used as a noun in Chinese. It only works as a verb. (This is quite the opposite of the example above of the gerundive lingzhe which he changed into a noun phrase.) Therefore, he refers to the entry on the verb "troosten" [to comfort]. This is not because of a linguistic difference but a matter of differences in the way of thinking. A similar case can be found in the long entry "Recht" (justice, law, right) (Schlegel 1884: 577-580), where he explains that "the notion of 'recht' is not so clear to the Chinese mind as to the Western mind, which transforms abstractions into concreta as a result of his mythological education."

It is beyond doubt that Schlegel considered his target user groups: his students in Leiden and his prospective users in the Dutch East Indies - after all, he was once a student and interpreter too, and he was aware of their needs. But of course, the information he provided was largely dependent on his own knowledge, interests, ideas and the availability of material.

\section{Conclusion}

Schlegel cited original Chinese texts to explain the syntactical properties of words and to illustrate authentic use of Chinese words. In many cases the inclusion of literary quotations helps the user to understand the meaning and use of the relevant word. The translation provided by Schlegel is mostly accurate and helpful to the user. The abundant choice in various literary works shows that Schlegel was well-read. Judging from the entries, it appears that he quoted randomly from different types of literary works which are written in a variety of levels and different registers of the Chinese language, ranging from the colloquial and dialect to formal and philosophical. These differences do not show in translation and it is questionable how the user would be able to determine suitability. Another problem is quoting out of context, in some cases it is difficult to understand the sentences on their own.

In spite of the fact that Schlegel was very much aware of his user situation and he set himself an aim of helping translators and students, and so in terms of lexicographic functions, the inclusion of literary quotations in the dictionary 
is primarily communication-orientated but to a certain extent also knowledgeorientated, in that it provides more than linguistic help. Nevertheless, it seems that Schlegel did not stick to his own "rules" and it seems more likely that he just used data that was available to him. Hence, in this context, the idea that Brewer puts forward that "Lexicographers deduce the meanings of words from their quotations (rather than deduce the meanings of their quotations from their pre-determined definitions)" is true also of Schlegel. That is in addition to the idea that words in quotations and their original definition function differently. Thus says Brewer, in the case of $O E D$ the inclusion of those quotes seems to be the result of cultural and not just linguistic intention on the part of the lexicographer. In the case of Schlegel, it is the result of cultural, linguistic and phraseological intention of the compiler.

Finally, the fact that Schlegel cites from a large variety of texts, not only the ones that count as "Chinese literary tradition" but also those that are considered "trivial literature" shows that his interest was quite broad. By including all the important works that make up the greater part of Chinese literary tradition, the dictionary maybe considered an anthology of Chinese literature. It is striking though that the more practical sample sentences derive from trivial literature, and seem to have a linguistic intention, whereas the culturally loaded sentences are quoted from works regarded as Chinese literature in the literary tradition and enlighten the user on important aspects of Chinese culture. Although this study is merely an interpretation of literary quotations included in an existing, very old, dictionary, hopefully the findings will contribute to the future development of lexicographic theories and practices. The issue of including literary quotations in the dictionary is in itself very important, and worth contemplation by prospective dictionary compilers. In the case of deciding to include literary quotations, hopefully the examples in this study will help shed light on their criteria and suitability.

\section{Acknowledgement}

Sincere gratitude to Professor Chan Man Sing and Professor Wu Cuncun at the School of Chinese, Hong Kong University (HKU), who arranged access to the Special Collections (Rare Books) at HKU libraries from January till June 2017, which enabled me to continue my research on the Dutch-Chinese dictionary compiled by Gustaaf Schlegel.

\section{Endnotes}

1. Kuiper 2017 for details on the training.

2. The full quote is: "At their best these novels, with their frequent disguises and misunderstandings, are reminiscent of eighteenth-century French comedies. At their worst, however, they are pedantic and soporific Chinese equivalents of the dime novel." Idema and Haft 1997: 227. 
3. There is also a versified version by Legge: Sought for her long, but all his search was vain./ Awake, asleep, he ever felt the pain/ of longing thought, as when on restless bed, / Tossing about, one turns his fevered head. (Minford and Lau 2002: 77).

\section{References}

\section{A. Dictionaries}

Douglas, Carstairs. 1873. Chinese-English Dictionary of the Vernacular or Spoken Language of Amoy. London: Trübner \& Co.

Francken, J.J.C. and C.F.M. de Grijs. 1882. Chineesch-Hollandsch woordenboek van het Emoi dialekt [Chinese-Dutch Dictionary of the Xiamen Dialect]. Batavia: Bataviaasch Genootschap van Kunsten en Wetenschappen.

Schlegel, Gustaaf. 1884. Nederlandsch-Chineesch Woordenboek met de Transcriptie der Chineesche Karakters in het Tsiang-Tsiu Dialekt. 荷華文語類參 Hô Hoâ Bûn-Gí Luī-Ts'am [Dutch-Chinese Dictionary with Transcription of Chinese Characters in Zhangzhou Dialect]. Volume $3(\mathrm{O}-\mathrm{S})$. Leiden: Brill.

Schlegel, Gustaaf. 1886. Nederlandsch-Chineesch Woordenboek met de Transcriptie der Chineesche Karakters in het Tsiang-Tsiu Dialekt. 荷華文語類參 Hô Hoâ Bûn-Gí Luī-Ts'am [Dutch-Chinese Dictionary with Transcription of Chinese Characters in Zhangzhou Dialect]. Volume $1(A-G)$. Leiden: Brill.

Schlegel, Gustaaf. 1887. Nederlandsch-Chineesch Woordenboek met de Transcriptie der Chineesche Karakters in het Tsiang-Tsiu Dialekt. 荷華文語類參 Hô Hoâ Bûn-Gí Luī-Ts'am [Dutch-Chinese Dictionary with Transcription of Chinese Characters in Zhangzhou Dialect]. Volume $2(\mathrm{H}-\mathrm{N})$. Leiden: Brill.

Schlegel, Gustaaf. 1890. Nederlandsch-Chineesch Woordenboek met de Transcriptie der Chineesche Karakters in het Tsiang-Tsiu Dialekt. 荷華文語類參 Hô Hoâ Bûn-Gí Luī-Ts'am [Dutch-Chinese Dictionary with Transcription of Chinese Characters in Zhangzhou Dialect]. Volume 4 (T-Z). Leiden: Brill.

\section{B. Other literature}

Adamska-Sałaciak, Arleta. 2010. Examining Equivalence. International Journal of Lexicography 23(4): 387-409.

Atkins, B.T. Sue and Michael Rundell. 2008. The Oxford Guide to Practical Lexicography. Oxford/ New York: Oxford University Press.

Bergenholtz, Henning and Sven Tarp. 2003. Two Opposing Theories: On H. E. Wiegand's Recent Discovery of Lexicographic Functions. Hermes, Journal of Linguistics 31: 171-196.

Brewer, Charlotte. 2010. The Use of Literary Quotations in the Oxford English Dictionary. The Review of English Studies (New Series) 61(248): 93-125.

Brokaw, Cynthia J. 2007. Commerce in Culture: The Sibao Book Trade in the Qing and Republican Periods. Cambridge, Mass.: Harvard University Press. 
Heijns, Audrey. 2020. In Pursuit of Genuine Chinese Equivalents: The Case of a Nineteenth-Century Dutch-Chinese Dictionary. International Journal of Lexicography 33(1): 104-115.

Idema, Wilt and Lloyd Haft. 1997. A Guide to Chinese Literature. Ann Arbor: Center for Chinese Studies, University of Michigan.

Kuiper, Koos (P.N.). 2017. The Early Dutch Sinologists (1854-1900): Training in Holland and China, Functions in the Netherlands Indies. Leiden: Brill.

Legge, James. 1875. The Chinese Classics. Volume 2: The Works of Mencius. London: Trübner.

McDougall, Bonnie S. 1971. The Introduction of Western Literary Theories into Modern China, 1919-1925. Tokyo: Centre for East Asian Cultural Studies.

Mencius. 2003. Translated by D.C. Lau. Hong Kong: Chinese University Press.

Minford, John and Joseph S.M. Lau (Eds.). 2002. Classical Chinese Literature. Volume I: From Antiquity to the Tang Dynasty. New York: Columbia University Press / Hong Kong: Chinese University Press.

Murck, Alfreda. 2000. Poetry and Painting in Song China: The Subtle Art of Dissent. Cambridge, Massachusetts/London: Harvard University Asia Center for the Harvard-Yenching Institute.

Osswald, Rainer. 2015. Syntax and Lexicography. Kiss, Tibor and Artemis Alexiadou. 2015. Syntax Theory and Analysis. An International Handbook. Volume 3: Syntax and Lexicography: 1963-2001. Handbücher zur Sprach- und Kommunikationswissenschaft / Handbooks of Linguistics and Communication Science (HSK) 42(3). Berlin: De Gruyter Mouton.

Schlegel, Gustaaf. 1892. La Stèle Funéraire du Téghin Giogh, et ses Copistes et Traducteurs Chinois, Russes, et Allemands [The Funerary Stele of Téghin Giogh, and its Copiers and Chinese, Russian and German Translators.] Leiden: Brill.

Wyllie, Alexander. 1964. (c1867.) Notes on Chinese Literature. New York: Paragon Book Reprint Corp. 